\title{
HUBUNGAN PENGETAHUAN PRIMIGRAVIDA TENTANG HIPERTENSI KEHAMILAN DENGAN KEPATUHAN MELAKUKAN ANC DI BPS Hj. SITI FATIMAH, Amd.Keb, KRIAN-SIDOARJO
}

\author{
Widya Anggraeni ${ }^{1 *}$, Kurnia Indriyanti Purnama Sari ${ }^{1}$ \\ ${ }^{1}$ STIKES Dian Husada Mojokerto \\ *Correspondence: \\ Widya Anggraeni \\ Email: widya_inggit@yahoo.co.id
}

\begin{abstract}
Background: Pengetahuan atau kognitif merupakan domain yang sangat penting dalam membentuk tindakan seseorang (overt behavior) (Notoadmodjo, 2003). Banyaknya angka kematian dan kesakitan pada ibu hamil disebabkan karena pengetahuan mereka yang rendah cenderung pemeliharaan kesehatan secara tradisional dan belum siap menerima pelaksanaan kesehatan modern, selain itu pengawasan antenatal (pemeriksaan kehamilan) masih belum memadai sehingga menyebabkan penyulit dalam kehamilan dengan resiko tinggi, misalnya timbul penyakit hipertensi kehamilan yang tidak diketahui secara dini.

Purpose: Tujuan penelitian ini adalah diketahuinya hubungan pengetahuan primigravida tentang hipertensi kehamilan dengan kepatuhan melakukan ANC di BPS Hj. Siti Fatimah, Amd. Keb, Krian Sidoarjo.

Method: Desain penelitian ini menggunakan desain cross sectional. Metode sampling yang digunakan adalah non probability samplingconcecutive sampling. Sampel yang diambil sebanyak 28 responden yaitu pada ibu primigravida yang melakukan pemeriksaan kehamilan di BPS Hj.Siti Fatimah, Amd.Keb di Desa Terungkulon Kecamatan Krian Kabupaten Sidoarjo yang pada bulan Juni - Juli 2015. Data penelitian ini diambil dengan menggunakan kuesioner dan lembar observasi. Setelah di tabulasi data yang ada dianalisis dengan menggunakan uji Spearman's Rho.

Results: Hasil penelitian menunjukkan setengahnya pengetahuan yang dimiliki primigravida tentang hipertensi kehamilan adalah pada kategori kurang yaitu 14 responden (50\%) dan sebagian kecil memiliki pengetahuan yang baik yaitu 4 responden (14,29\%). Sedangkan kepatuhan primigravida dalam melakukan ANC sebagian besar tidak teratur yaitu 18 responden (64,29\%) dan hampir setengahnya teratur dalam melakukan ANC yaitu 10 responden (35,71\%). Dari hasil pengujian statistik diperoleh hasil ada hubungan antara pengetahuan primigravida dengan kepatuhan dalam melakukan ANC dengan nilai koefisien korelasi sebesar 0,548 dengan tingkat signifikan 0,003 ( $\rho<$ $0,05)$.

Conclusion: Berdasarkan hasil penelitian diharapkan tenaga kesehatan dapat memberikan informasi tentang pentingnya proses antenatal care.

Key words: pengetahuan, antenatal care, primigravida
\end{abstract}

\section{PENDAHULUAN}

Pengetahuan atau kognitif merupakan domain yang sangat penting dalam membentuk tindakan seseorang (overt behavior) (Notoadmodjo, 2003). Banyaknya angka kematian dan kesakitan pada ibu hamil disebabkan karena pengetahuan mereka yang rendah cenderung pemeliharaan kesehatan secara tradisional dan belum siap menerima pelaksanaan kesehatan modern, selain itu pengawasan antenatal (pemeriksaan kehamilan) masih belum memadai sehingga menyebabkan penyulit dalam kehamilan dengan resiko tinggi, misalnya timbul penyakit hipertensi kehamilan yang 
tidak diketahui secara dini. Hal ini terjadi dikarenakan banyak ibu hamil terutama primigravida yang tidak mengetahui manfaat dari ANC (Ante Natal Care), padahal melalui ANC dapat mengenal dan menangani sedini mungkin kelainan yang terdapat pada saat hamil, persalinan dan nifas.

Hasil analisis menunjukkan antara $5 \%$ dan $8 \%$ kehamilan mendapat komplikasi hipertensi (Derek Llewellyn, 2002:113). Kejadian hipertensi dalam kehamilan cukup tinggi ialah 5-15\%, merupakan satu antara tiga penyebab mortalitas (kematian) dan morbiditas (kejadian) ibu bersalin selain infeksi dan perdarahan. Hal itu dikarenakan angka kejadian yang tinggi dan penyakit ini mengenai semua lapisan masyarakat. (http://bkkbn.go.id). Kemudian insiden hipertensi pada kehamilan ini lebih banyak pada ibu primigravida $(53,7 \%)$, sedangkan ibu yang tidak mengalami hipertensi frekuensinya lebih banyak pada ibu multigravida $(73,6 \%)$, berarti kejadian hipertensi kehamilan masih saja terjadi. (http://repository.usu.ac.id /handle/ 123456789/14603). Dari studi pendahuluan pada tanggal 05 - 20 Mei 2015 terdapat 30 ibu primigravida yang melakukan ANC di BPS Hj. Siti Fatimah, Amd.Keb dan dari ibu hamil tersebut terdapat 12 ibu yang mengalami hipertensi kehamilan. Yang melakukan ANC secara teratur sebanyak 5 orang $(42 \%)$ dan yang tidak melakukan ANC secara teratur sebanyak 7 orang $(58 \%)$.

Pemeriksaan Antenatal Care (ANC) sangat penting dilakukan untuk ibu hamil, karena Antenatal Care (ANC) dapat menyiapkan fisik, mental ibu serta menyelamatkan ibu dan anak dalam kehamilannya agar tidak terjadi komplikasi. Namun kenyataannya tidak dilakukan oleh ibu hamil di desa Terungkulon . Adapun faktor yang menyebabkan ibu hamil tersebut tidak melakukan pemeriksaan kehamilan dikarenakan ekonomi dan kurangnya informasi bagi ibu hamil apalagi primigravida tentang manfaat ANC. Karena kurangnya pengetahuan inilah yang menjadi pemicu utama ibu hamil untuk tidak melakukan pemeriksaan ANC, sehingga mengakibatkan ibu kurang mengetahui perkembangan kesehatan dirinya serta janinnya dan komplikasi yang timbul apabila tidak diketahui secara dini.

Untuk mengatasi masalah tersebut ibu hamil harus diberikan suatu konseling dan penyuluhan mengenai penyakit hipertensi dalam kehamilan serta dampak yang ditimbulkannya seperti terjadinya kematian pada ibu maupun janin. Sehingga, akan memberikan suatu motivasi pada ibu hamil untuk melakukan pemeriksaan kehamilan secara rutin yaitu sedikitnya 4 kali.

Tujuan umum penelitian ini adalah Diketahuinya hubungan pengetahuan ibu primigravida tentang hipertensi dalam kehamilan dengan kepatuhan melakukan ANC.

\section{METODE DAN BAHAN}

Penelitian ini rancangan penelitian yang digunakan adalah teknik cross sectional yaitu peneliti melakukan observasi atau pengamatan variabel pada satu saat (point time approach). Rancangan penelitian menggunakan rancangan penelitian cross sectional. Sebagai populasi dalam penelitian ini adalah seluruh ibu hamil primigravida yang melakukan pemeriksaan kehamilan di BPS $\mathrm{Hj}$. Siti Fatimah, Amd.Keb Ds. Terungkulon- 
Krian Sidoarjo sebanyak 28 responden. Teknik pengambilan sampel yang dilakukan pada penelitian adalah consecutive sampling. Instrumen yang digunakan dalam penelitian ini adalah kuesioner dan lembar observasi. Data yang diperoleh dianalisis dan disajikan dalam bentuk tabel frekuensi.

\section{HASIL PENELITIAN}

1. Pengetahuan primigravida tentang hipertensi kehamilan di BPS Hj. Siti Fatimah, Amd.Keb.

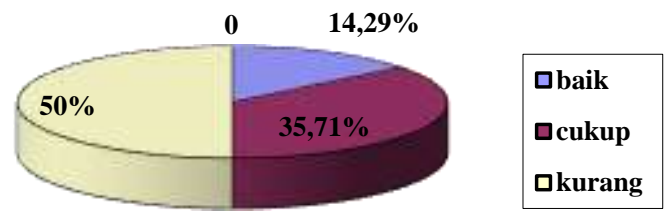

Gambar 1. Diagram Pie Tingkat Pengetahuan Primigravida tentang Hipertensi Kehamilan di BPS Hj. Siti Fatimah, Amd.Keb., Krian-Sidoarjo

\begin{tabular}{llrrr}
\multicolumn{2}{c}{ Berdasarkan } & gambar & diatas \\
didapatkan & bahwa & 28 & responden \\
primigravida & setengahnya & memiliki \\
pengetahuan & kurang & sebanyak & 14 \\
responden $(50 \%)$ & dan & sebagian & kecil \\
memiliki pengetahuan & baik & sebanyak 4 \\
responden $(14,29 \%)$.
\end{tabular}

Berdasarkan gambar diatas didapatkan bahwa 28 responden primigravida setengahnya memiliki pengetahuan kurang sebanyak 14 responden $(50 \%)$ dan sebagian kecil responden $(14,29 \%)$.
2. Kepatuhan primigravida dalam melakukan ANC di BPS Hj. Siti Fatimah, Amd.Keb.

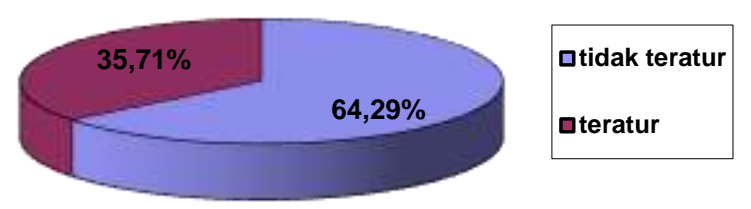

Gambar 2. Diagram Pie Tingkat Kepatuhan Primigravida dalam Melakukan ANC di BPS Hj. Siti Fatimah, Amd.Keb., Krian-Sidoarjo

Berdasarkan gambar diatas dapat dilihat bahwa dari 28 responden primigravida sebagian besar tidak teratur dalam melakukan ANC sebanyak 18 responden $(64,29 \%)$ dan hampir setengahnya teratur dalam melakukan ANC sebanyak 10 responden $(35,71 \%)$.

3. Hubungan

pengetahuan primigravida tentang hipertensi kehamilan dengan kepatuhan melakukan ANC di BPS Hj. Siti Fatimah, Amd.Keb Desa Terungkulon Kecamatan Krian Kabupaten Sidoarjo.

Tabel 1. Analisa Hubungan antara Pengetahuan Primigravida tentang Hipertensi Kehamilan dengan Kepatuhan Melakukan ANC di BPS Hj. Siti Fatimah, Amd.Keb., Krian-Sidoarjo.

\begin{tabular}{|c|c|c|c|c|c|c|c|}
\hline \multirow{2}{*}{$\begin{array}{c}\mathrm{N} \\
\mathrm{o}\end{array}$} & Pengetahuan & \multicolumn{2}{|c|}{ Teratur } & \multicolumn{2}{c|}{ Tidak teratur } & Jumlah & $\begin{array}{c}\text { Persentase } \\
(\%)\end{array}$ \\
\cline { 3 - 8 } & & $\mathrm{n}$ & $\%$ & $\mathrm{n}$ & $\%$ & & \\
\hline 1. & Kurang & 2 & 7,14 & 12 & 42,86 & 14 & 50 \\
2. & Cukup & 4 & 14,28 & 6 & 21,43 & 10 & 35,71 \\
3. & Baik & 4 & 14,29 & 0 & 0 & 4 & 14,29 \\
\hline \multicolumn{8}{|c|}{ Uji Spearman's Rho dengan $\rho=0,003$} \\
\hline
\end{tabular}


Berdasarkan hasil uji Spearman's Rho pada tabel 1 diatas didapatkan bahwa $\rho=0,003<0,05$, sehingga $\mathrm{H} 0$ ditolak dan $\mathrm{H} 1$ diterima yang artinya ada hubungan yang bermakna antara Pengetahuan Primigravida Tentang Hipertensi Kehamilan Dengan Kepatuhan Melakukan ANC. Interpretasi terhadap koefisien korelasi memiliki tingkat hubungan sedang.

\section{PEMBAHASAN}

Menurut Roger (1987) bahwa penerimaan atau adanya perilaku kesehatan akan melalui proses atau tahapan. Salah satu tahapan tersebut adalah adanya pengetahuan. Pendapat ini juga mendukung hasil penelitian yang mana semakin tinggi pengetahuan primigravida tentang hipertensi kehamilan maka semakin teratur sikap primigravida dalam melakukan ANC. Adapun tujuan dari ANC diantaranya yaitu untuk memantau kemajuan kehamilan untuk memastikan kesehatan ibu dan tumbuh kembang janin, selain itu juga untuk mengenali secara dini adanya komplikasi yang mungkin terjadi selama hamil (Sarwono, 2002).

\section{SIMPULAN}

Berdasarkan hasil penelitian Hubungan pengetahuan primigravida tentang hipertensi kehamilan dengan kepatuhan dalam melakukan ANC di BPS Hj. Siti Fatimah, Amd.Keb., Desa Terungkulon Kecamatan Krian Kabupaten Sidoarjo ada hubungan antara pengetahuan primigravida tentang hipertensi kehamilan dengan kepatuhan melakukan ANC. Semakin baik pengetahuan ibu tentang hipertensi kehamilan maka semakin teratur ibu melakukan ANC. Demikian juga sebaliknya semakin kurang pengetahuan ibu tentang hipertensi kehamilan maka ibu tidak akan teratur dalam melakukan ANC.

Dengan tingkat kemaknaan 0,05 didapatkan angka signifikansinya 0,003 ( $\rho$ $<0,05)$. Dan dalam interpretasi terhadap koefisien korelasi memiliki tingkat hubungan sedang.

\section{SARAN}

1. Diharapkan Ibu hamil terutama primigravida banyak mencari Informasi melalui media elektronik atau tertulis guna untuk meningkatkan pemahaman dan pengetahuan tentang hipertensi dalam kehamilan manfaat melakukan ANC secara teratur.

2. Hendaknya dilakukan pengkajian yang lebih dalam tentang pengetahuan yang berhubungan dengan hipertensi dalam kehamilan yang saat ini banyak terjadi terutama pada primigravida serta dampak apabila tidak teratur dalam melakukan ANC.

3. Petugas kesehatan seharusnya lebih interaktif dalam memberikan informasi kesehatan khususnya terhadap primigravida tentang hipertensi dalam kehamilan dengan manfaat melakukan ANC secara teratur.

\section{DAFTAR PUSTAKA}

1. Alimul H. Aziz. 2003. Riset Keperawatan dan Teknik Penulisan Ilmiah, Edisi 1. Jakarta: Salemba Medika.

2. Ayurai. 2009. ANC (pemeriksaan kehamilan). www.wordpress.com.

3. BKKBN. 2009. Hipertensi dalam kehamilan.

http://bali/bkkbn.go.id/new/article detail.php?aid=31.

4. Azwar, Saifudin. 2007. Sikap Manusia, Edisi 2. Yogyakarta: Pustaka Pelajar. 
5. Manuaba, Ida Bagus Gde. 2001. Kapita Selekta Penatalaksanaan Rutin Obstetri Ginekologi Dan KB. Jakarta: EGC.

6. Manuaba, Ida Bagus Gde. 2003. Kapita Selekta Penatalaksanaan Rutin Obstetri Ginekologi Dan KB. Jakarta: EGC.

7. Nazir, Moh D. 2005. Metode Penelitian, Edisi VI. Jakarata: Ghalia Indonesia.

8. Niven, Neil. 2000. Psikologi Perilaku, Edisi kedua. Jakarta: EGC.

9. Notoadmodjo, Soekidjo. 2003. Pendidikan dan Perilaku Kesehatan. Jakarta: EGC.

10. Notoadmodjo, Soekidjo. 2005. Metodologi Penelitian Kesehatan. Jakarta: Rineka Cipta.

11. Nursalam. 2003. Konsep dan Penerapan Metodelogi Penelitian Ilmu Keperawatan, Edisi 1. Jakarta: Salemba Medika.

12. Prawirohardjo, Sarwono. 2002. Buku Acuan Nasional Pelayanan Kesehatan Maternal dan Neonatal, Edisi I. Jakarta: YBP.

13. Rosmaliana, Eli. 2009. Perbedaan Berat Badan Lahir Bayi Yang Dilahirkan Oleh Ibu Yang Mengalami Hipertensi Dengan Ibu Yang Tidak Mengalami Hipertensi. http://repository.usu.ac.id/handle/1234 56789/14603.

14. Salmah. 2006. Asuhan kebidanan Antenatal. Jakrata: EGC.

15. Sastroasmoro,Sudigdo. 2002. DasarDasar Metodologi Penelitian,Edisi 2. Jakarta: Sugeng Seto.

16. Setiadi. 2007. Konsep dan Penulisan Riset Keperawatan, Edisi 1. Yogyakarta: Graha Ilmu.
17. Sugiyono 2007. Statistika Untuk Penelitian, Cetakan ke-12. Bandung: CV ALFABETA. 